\title{
Clinical and Radiographic Assessment of cyanoacrylates Opposing Buccal sliding flap for the immediate repair of Oroantral communication
}

\author{
Original \\ Article \\ Maggie A Khairy ${ }^{a}$ and Inas A Abulmagd \\ ${ }^{a}$ Department of Oral and Maxillofacial Surgery, Faculty of Dentistry, October \\ 6 University, ${ }^{b}$ Department of Oral radiology, Faculty of Dentistry, AlFayoum \\ University, Egypt
}

\begin{abstract}
Introduction: Oroantral communication is an uncommon, inadvertent incident resulting from various causes the most common of which is the extraction of upper molars. Immediate closure of the communication is highly recommended to avoid infection and subsequent fistulous tract formation. Cyanoacrylate tissue glue was introduced as a reliable method for flapless sealing of the communication without any of the complications associated with the surgical maneuvers. One of the oldest surgical procedures used for closure of the Oroantral communication is the buccal advancement flap which proved efficiency in complete closure of the defect with minimal related complications.

Aim of the study: The study aims evaluate the immediate flapless closure of Oroantral communication using cyanoacrylates versus the buccal sliding advancement flap.

Patients and Methods: Twenty patients suffering from instant oroantral communication were included in the study. CBCT was performed to each of them to confirm the diagnosis, patients were divided into two groups where Group I (Study group) patients were treated by sealing of the defect using periacry $190 \mathrm{HV}$ while Group II (control group) patients performed Buccal sliding advancement flap. Clinical follow up including pain, facial swelling, recurrence of the defect and sulcular depth up were performed at day 1, 3, 7, 15 and 1 month. CBCTs were done at 3 and 6 months postoperative to assess healing of the defect regarding size and density.

Results: Clinically Group I showed minimal pain and swelling with no change of sulcular depth. In contrast, Group II showed high pain level and increase in facial swelling together with a significant decrease in sulcular depth. None of the patients in both groups showed any recurrence of the condition. CBCTs showed decrease in defect size and formation of bone within the defect in both groups.

Conclusion: Both maneuvers are good modalities for treating OAC, however cyanoacrylate is associated with minimal complications.
\end{abstract}

Key Words: CBCT, Cyanoacrylates, Dermoid Buccal flap, Oroantral communication.

Received: 29 May 2020, Accepted: 30 September 2020.

Corresponding Author: Maggie A. Khairy, Department of Oral and Maxillofacial Surgery, Faculty of Dentistry, October 6 University. Egypt, Tel.: +202264864, Mobile: +201060000949, E-mail: maggie_khairy@yahoo.com.

ISSN: 2090-097X, April 2020, Vol. 11, No. 2

\section{INTRODUCTION}

Oro-antral communication (OAC) is the inevitable connection between the oral cavity and the maxillary sinus. The most reputable cause of the condition is the extraction of maxillary molars due to the close proximity of their roots to the antral floor which is very thin in this area ${ }^{[1,2]}$. Moreover, periapical infection, large cysts, tumors and trauma can all be potential causes of oroantral communication $^{[3,4]}$. It is of utmost importance to close this patent connection as soon as it is recognized to preclude the development of sinusitis with subsequent fistula formation $^{[5]}$. Several articles recommended the closure of this communication within 24 hours of the incident ${ }^{[6]}$.

Affirmation on the presence of OAC is established through several procedures comprised of clinical examination including Valsalva test, Cheek blowing test and probing of the perforation site through the socket however, this specific technique is not favored anymore as it is associated with several complications as increasing size of the defect and the possible pushing of foreign bodies or bacteria into the maxillary sinus ${ }^{[7,8]}$.

Clinical diagnosis must be followed by radiological confirmation to exclude the presence of any dental roots or foreign bodies near or within the vicinity of the antrum. Radiographs provide accurate assessment of the site and size of the defect. Radiographic maneuvers commonly used are periapical, panoramic view ${ }^{[9]}$. Computerized Tomography (CT) as well as Cone beam computerized Tomography (CBCT). Nowadays, CBCT is widely used due its high quality, available 3D images, low radiation dose and the accurate details with less artifacts than helical 
CT. Oroantral communications are presented in CBCT as sinus floor disruption giving way to a clear interconnection between the oral cavity and the sinus ${ }^{[10,11]}$.

Several treatment options were postulated for the immediate closure of $\mathrm{OAC}$, these are either conservative or surgical maneuvers. It is to be mentioned that the size and site of the defect strongly influences the treatment of choice. It is commonly agreed that a defect within $2 \mathrm{~mm}$ can heal spontaneously providing the stability of blood clot is secured and total absence of infection throughout the healing period ${ }^{[12,13]}$. On the other hand, larger defects are managed in a different way; they were for long treated using local flaps. Different types of flaps proved efficient including buccal, palatal, tongue together with nasolabial flaps. Also, combinations of different types according to the size and site of the defect were used successfully ${ }^{[14,15]}$.

One of the oldest surgical procedures to treat Oroantral communication is the buccal sliding flap. Rehramnn was the first to introduce this flap in 1945 and since then it gained wide popularity owing to its ease of technique, reliability and versatility. However, several drawbacks were associated with this procedure including loss of sulcular depth, pain and edema ${ }^{[16,17]}$.

Conservative means of $\mathrm{OAC}$ closure were strongly advocated by several articles where acrylic splints, platelet rich fibrin, fibrin glue, collagen membrane and cyanoacrylates were used as efficient substitutes for the regular surgical procedures to bypass their side effects $^{[18,19]}$

Cyanoacrylates were first introduced to the medical field in the $1940 \mathrm{~s}$, the widely used forms were polymers of N-butyl cyanoacrylate, and 2-octyl cyanoacrylate. These polymers activate in the presence of moisture forming a tight chain between the two surfaces to be bonded in a hasty process lasting only $10-15$ seconds. These structural properties permitted boosting of the coagulation process and building a mechanical barrier at the site of tissue breakdown ${ }^{[20]}$. Thus Cyanoacrylates are regarded as an acceptable alternative to wound suturing due to the decreased time taken for wound closure and reduced incidence of surgical site infection ${ }^{[21,22]}$.

Unfortunately, the process of activation of cyanoacrylates is exothermic which can cause tissue damage. In order to attenuate the harmful effects of heat generation, long chains of methyl group were added to prolong the polymerization process thus decreasing the rate of heat generation ${ }^{[23]}$.

Nowadays, Cyanoacrylates are incorporated in various procedures within the medical field owing to their competence in corneal surgery, hemostasis of gastrointestinal bleeding, obliteration of urinary tract fistulae, cerebrospinal fistulae in addition to its utilization in skin graft fixation ${ }^{[24-26]}$
In Oral and Maxillofacial surgery cyanoacrylates are used in osteosynthesis of mandibular fractures, bone grafts, alveolar and palatal clefts ${ }^{[27,28]}$. Also, Cyanoacrylates were proved to accelerate the healing process within lacerations and perforations, to possess an antibacterial effect, decreases incidence of infection ${ }^{[29]}$ and to promote healing and maintain hemostasis within sockets after tooth extraction Moreover, Cyanoacrylates were related to decrease scarring in extraoral wounds ${ }^{[30,31]}$.

Periacryl 90 is a newly formulated cyanoacrylate polymer; its formula is designed to perform, specifically in the oral cavity. PeriAcryl ${ }^{\circledR} 90 \mathrm{HV}^{*}$ is an ideal blend of n-butyl cyanoacrylate and 2-octyl cyanoacrylate that has the perfect set of properties to function on soft tissue. The N-butyl cyanoacrylate contributes to the fast-setting characteristics while the 2-octyl component makes the dressing flexible and more comfortable on the soft tissues $^{[32]}$.

There is a lack of adequate evidence regarding effects of cyanoacrylate on the healing process of the sinus membrane. Therefore, the present study aims to assess clinical and radiological efficacy of cyanoacrylates in flapless closure of acute oroantral communication.

\section{PATIENTS AND METHODS}

The present study was carried out in the Oral surgery and Maxillofacial Department, Faculty of Dentistry, October 6 University. A total of 20 patients suffering from instant oroantral communication during inadvertent extraction of upper molars were incorporated in the study. Diagnosis and confirmation of the presence of OAC was based on clinical and radiological examinations.

\section{Clinical examination was based on:}

1. Clinical inspection.

2. Valsalva test: asking patients to exhale air while pressing their nostrils, air bubbles were seen getting out of the socket.

Radiological Examination: After confirmation of clinical examination immediate $C B C T$ scans were arranged for all patients to verify the following findings:

1. Communication between the maxillary sinus and oral cavity with size range $5-8 \mathrm{~mm}$.

2. Preserved intact buccal and palatal lamellar bone.

3. Absence of any tooth fragment or foreign body within the sinus

\section{Patients were excluded from the study if:}

1. They suffer from any chronic systemic disease or on regular medication.

2. Presence of any foreign material within the sinus. 
3. Presence of periapical infection.

4. Smokers.

All Patients were acknowledged of both study procedures and all related possible complications. Upon approval on both study regimens, all patients signed a written consent to be operated on by either of the two procedures. The study was approved by the ethics committee of Faculty of Dentistry, October 6 University.

Patients who fitted the inclusion criteria were 12 males and 8 females with age range 29 - 62 years. Patients were randomly divided into two equivalent groups where Group I patients had their OAC closed using collagen sponge soaked with periacryl HV $90^{1}$ (cyanoacrylate) (Figure 1), while Group II patients were treated using buccal advancement flap.

\section{Group I procedure (Study Group):}

Closure of the communication was performed under local anesthesia (Buccal and palatal infiltration) containing vasoconstrictor. The site of the defect was copiously irrigated with saline solution then inspected for any gingival tears or sharp bony edges which should be trimmed before commencing with the maneuver.

A collagen cone (Parasorb cone) $)^{2}$ was cut to appropriate size, soaked totally with Periacryl then inserted gently inside the socket. After completely adapting the collagen pellet inside the socket a uniform layer of Periacryl * 90 HV was applied on top of the collagen to completely seal the socket (Figure 2).

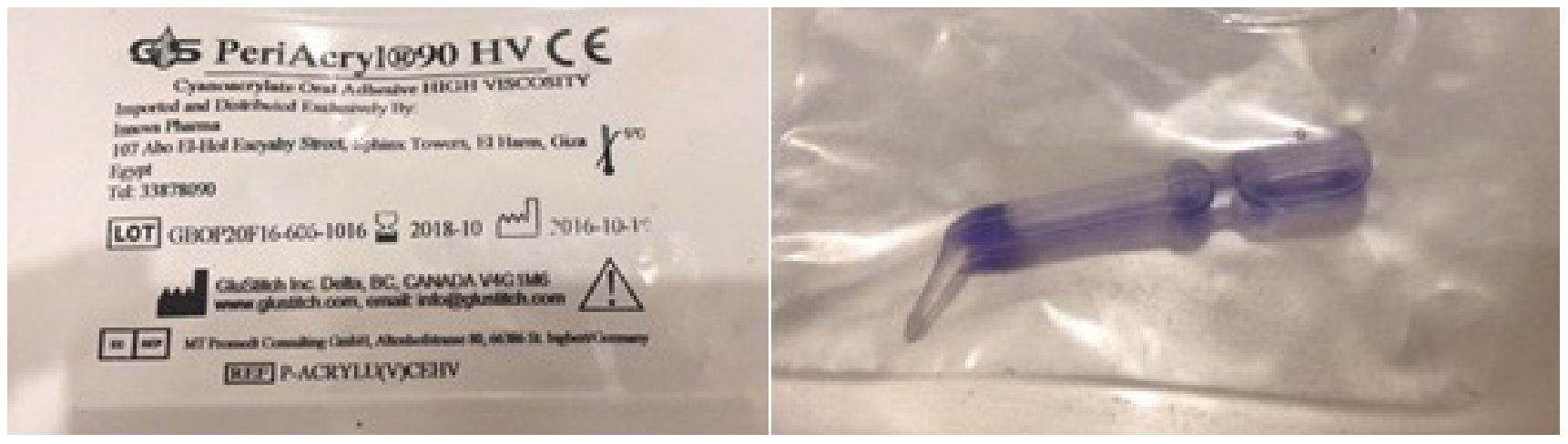

Figure 1: Periacryl HV 90 supplied in ampules.
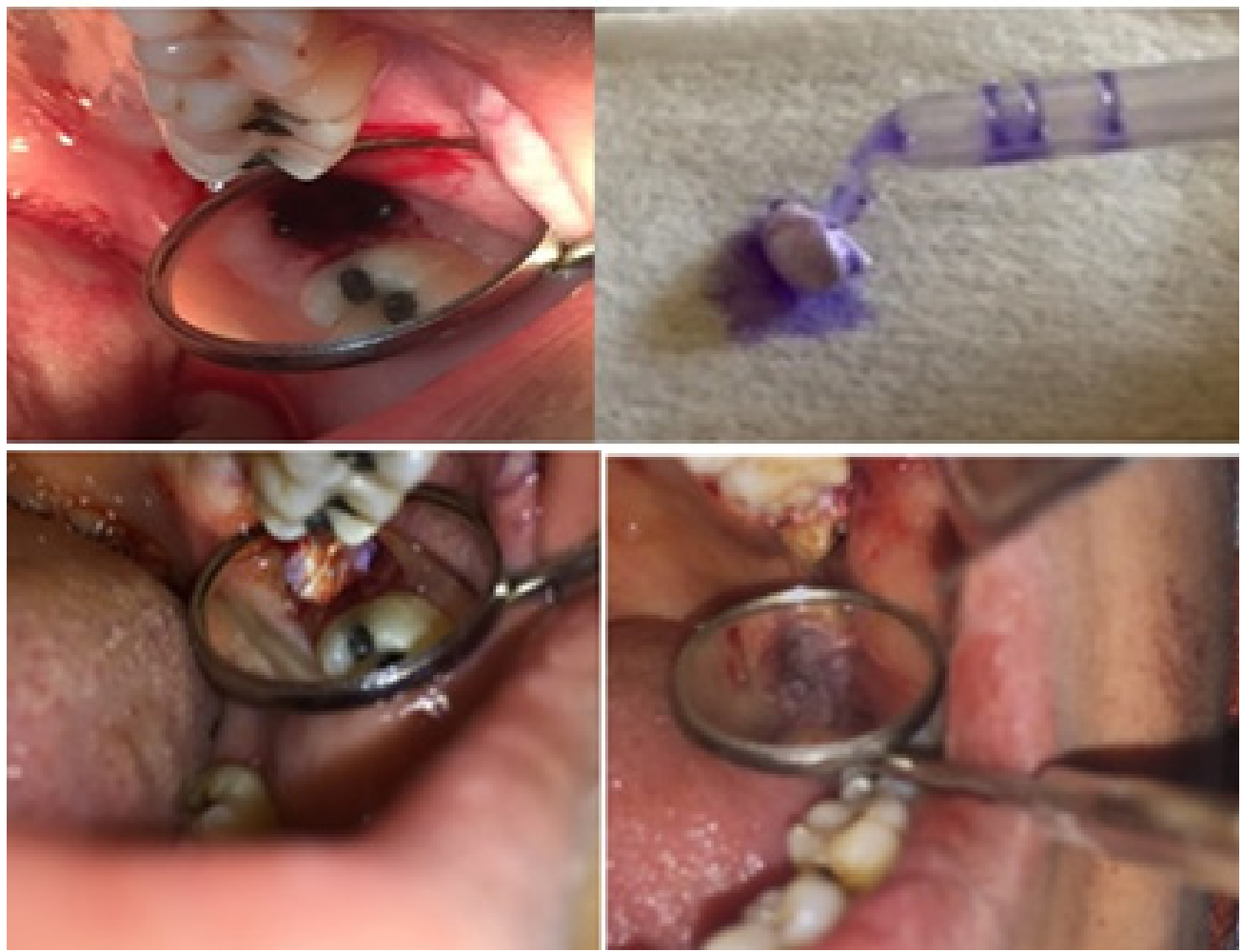

Figure 2: A: irrigation of the socket, B: collagen cone cut and soaked with periacryl, C: collagen cone inserted in the socket, D: socket is completely soaked with periacryl. 


\section{Group II Procedure (Control Group):}

Patients of group II received local anesthesia Lidocaine $2 \%$ with epinephrine. The socket was copiously irrigated with saline to remove any debris or any related tooth structure. A Trapezoidal mucoperiosteum buccal flap was performed by making two sharp divergent incisions through the mucoperiosteum to bone and carried superiorly to the height of the mucobuccal fold. The periosteum on the under surface of the flap was incised horizontally at the base of the flap to allow ease of flap advancement. The extraction socket was closed by sliding the buccal flap over the socket and suturing the flap to the undermined palatal mucosa. Sutures were done using silk 3 - 0 which was removed after 10 days (Figure 3 ). represented the absence of pain (score 0 ) and the right most end indicated the most severe pain (score 10).

- Facial swelling was assessed using the modified Gabka and Matsamura ${ }^{[33]}$ technique .Using a soft tape three measurements were recorded, tragus to the outer corner of the nose, tragus to the outer corner of the mouth, and lateral corner of the eye to the angle of the mandible. The sum of the 3 preoperative measurements was taken as the baseline. The difference between the maximum postoperative measurement and the baseline gave the value of facial swelling for each patient.

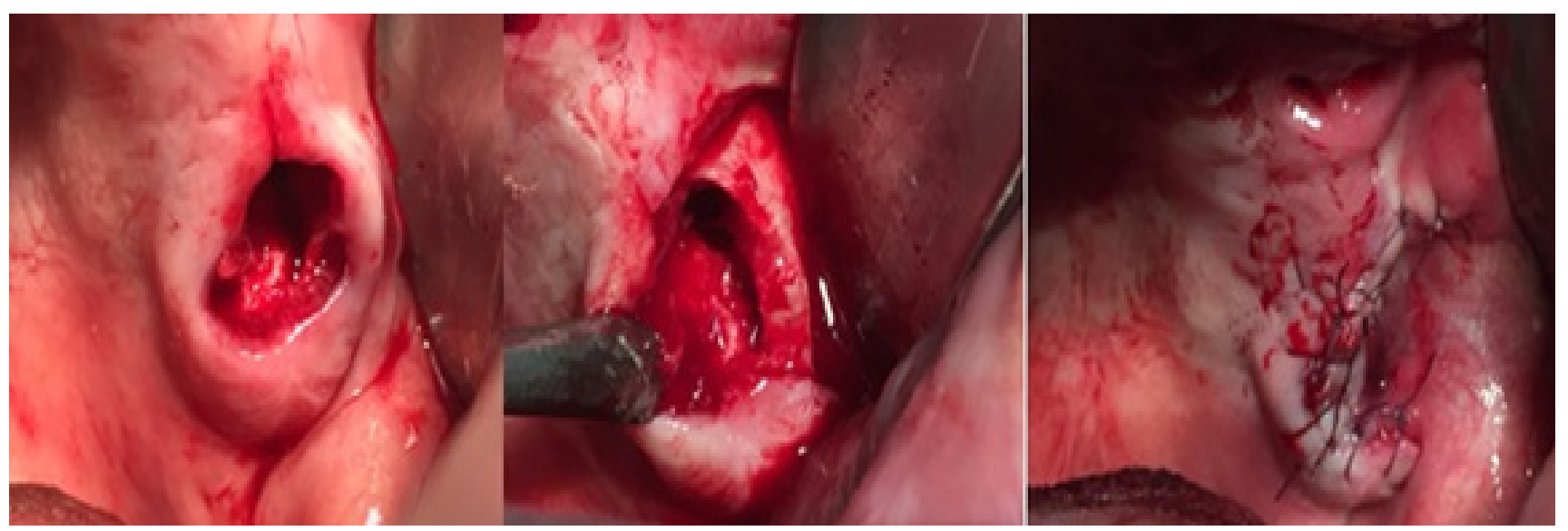

Figure 3: A: Socket after irrigation, B: buccal advancement flap C: repositioning and suturing of the flap.

Postoperative instructions and medications were the same for both groups. All patients were warned to avoid consuming hot food or drinks, nose blowing, sneezing with closed mouth or any form of negative or positive pressure for 1 week postoperative.

All patients were prescribed Augmentin 1 gm/12 hrs for one week, Paracetamol ${ }^{4} 500 \mathrm{mg}^{*} / 12 \mathrm{hrs}$ for one week and were advised to use it whenever necessary. Nasal decongestants * were also prescribed $3 \mathrm{qed} / 7$ days. Sutures were removed after 10 days in Group II patients.

${ }^{1}$ Resorba Medical GmbH.

${ }^{2}$ Periacryl ${ }^{\circledR} 90 \mathrm{HV}$ glustitch.

${ }^{3}$ GlaxoSmithKline, UK.

${ }^{4}$ Misr company.

\section{Postoperative Evaluation:}

\section{Clinical Follow up:}

Clinical postoperative data collected were:

- Pain was assessed using a visual analogue scale (VAS) of 10 units in combination with a graphic rating scale. On the VAS, the left most end
- Vestibular depth: was assessed using graded periodontal probe.

- Persistence of the communication is evaluated through asking the patient about signs of $\mathrm{OAC}$ and by clinical examination.

Clinical data were collected at 1, 3, 7, 15 days and 1 month postoperatively.

\section{Radiographic evaluation:}

CBCTs were done for each patient preoperatively and at 1 month and 3 months postoperative to evaluate the following:

- $\quad$ The defect size was measured both buccolingually and mesiodistally by taking average of three readings from three different planes.

- The bone density at the site of the defect was measured using software of Planmeca (Romexis Planmeca, Planmeca, Finland).

\section{Statistical Analysis:}

Numerical data were explored for normality by checking the distribution of data and using tests of normality (Kolmogorov-Smirnov and Shapiro-Wilk tests). All data showed normal (parametric) distribution except 
for pain scores which showed non-normal (non-parametric) distribution. Parametric data were presented as mean, standard deviation (SD) and 95\% Confidence Interval (95\% CI) values. Non-parametric data were presented as median and range values. For parametric data. Student's t-test was used to compare between mean age values in the two groups. Repeated measures ANOVA test was used to compare between mean swelling, vestibular width, defect size and density in the two groups as well as to study the changes by time within each group. Bonferroni's post-hoc test was used for pair-wise comparisons when ANOVA test is significant. For non-parametric data, Mann- Whitney U test was used to compare between the two groups. Friedman's test was used to study the changes by time within each group. Dunn's test was used for pairwise comparisons. Qualitative data were presented as frequencies and percentages. Fisher's Exact test was used for comparisons between the groups. The significance level was set at $P \leq 0.05$. Statistical analysis was performed with IBM SPSS Statistics for Windows, Version 23.0. Armonk, NY: IBM Corp.

\section{RESULTS}

\section{Demographic data:}

Results revealed no statistically significant difference between mean age values or gender distribution in the two groups.
Table 1: Mean, standard deviation (SD), frequencies (n), percentages and results of Student's t-test and Fisher's Exact tests for comparisons of demographic data in the two groups:

\begin{tabular}{llll}
\hline Case & $\begin{array}{l}\text { Group I } \\
(\mathrm{n}=10)\end{array}$ & $\begin{array}{l}\text { Group II } \\
(\mathrm{n}=10)\end{array}$ & $P$-value \\
\hline Age (Years) & & & \\
$\begin{array}{l}\text { Mean (SD) } \\
\text { Gender [n (\%)] }\end{array}$ & $46.1(10.7)$ & $46.4(12.3)$ & $0.954^{*}$ \\
Female & $4(40)$ & $5(50)$ & 1.000 \\
Male & $6(60)$ & $5(50)$ & \\
\hline
\end{tabular}

*: Significant at $P \leq 0.05$.

\section{Pain Scores (VAS 0-10):}

Pain scores revealed significant lower pain scores in Group I in respect to Group I at 3 as well as 7 days respectively. However, there was no demonstrated statistically significant difference between the two groups at 15 days as well as 1 month. (Table 2, Figure 4). Obviously, pain levels decreased by time within the two groups yet group I patients scored less pain levels as early as 1 and 7 days postoperative.

Table 2: Descriptive statistics and results of Mann-Whitney U test for comparison between pain scores in the two groups and Friedman's test for the changes by time within each group:

\begin{tabular}{|c|c|c|c|c|c|c|}
\hline \multirow[t]{2}{*}{ Time } & \multicolumn{2}{|c|}{$\begin{array}{l}\text { Group I } \\
(\mathrm{n}=10)\end{array}$} & \multicolumn{2}{|c|}{$\begin{array}{l}\text { Group II } \\
(\mathrm{n}=10)\end{array}$} & \multirow[t]{2}{*}{ P-value } & \multirow[t]{2}{*}{ Effect size (d) } \\
\hline & Median & Range & Median & Range & & \\
\hline 1 day & $8.5^{\mathrm{A}}$ & $7-10$ & $9.5^{\mathrm{A}}$ & $9-10$ & $0.027 *$ & 1.050 \\
\hline 3 days & $5^{\text {в }}$ & $4-7$ & $8.5^{\mathrm{B}}$ & $7-10$ & $<0.001^{*}$ & 2.407 \\
\hline 7 days & $1.5^{\mathrm{C}}$ & $0-3$ & $4.5^{\mathrm{c}}$ & $2-6$ & $<0.001^{*}$ & 2.616 \\
\hline 15 days & $0^{\mathrm{D}}$ & $0-1$ & $0^{\mathrm{D}}$ & $0-2$ & 0.503 & 0.187 \\
\hline 30 days & $0^{\mathrm{D}}$ & $0-0$ & $0^{\mathrm{D}}$ & $0-0$ & 1.000 & 0.000 \\
\hline $\begin{array}{l}\text { P-value (Changes } \\
\text { by time) }\end{array}$ & \multicolumn{2}{|c|}{$<0.001 *$} & \multicolumn{2}{|c|}{$<0.001^{*}$} & & \\
\hline Effect size (w) & \multicolumn{2}{|c|}{0.955} & \multicolumn{2}{|c|}{0.968} & & \\
\hline
\end{tabular}

*: Significant at $P \leq 0.05$, Different superscripts in the same column indicate statistically significant changes by time. 


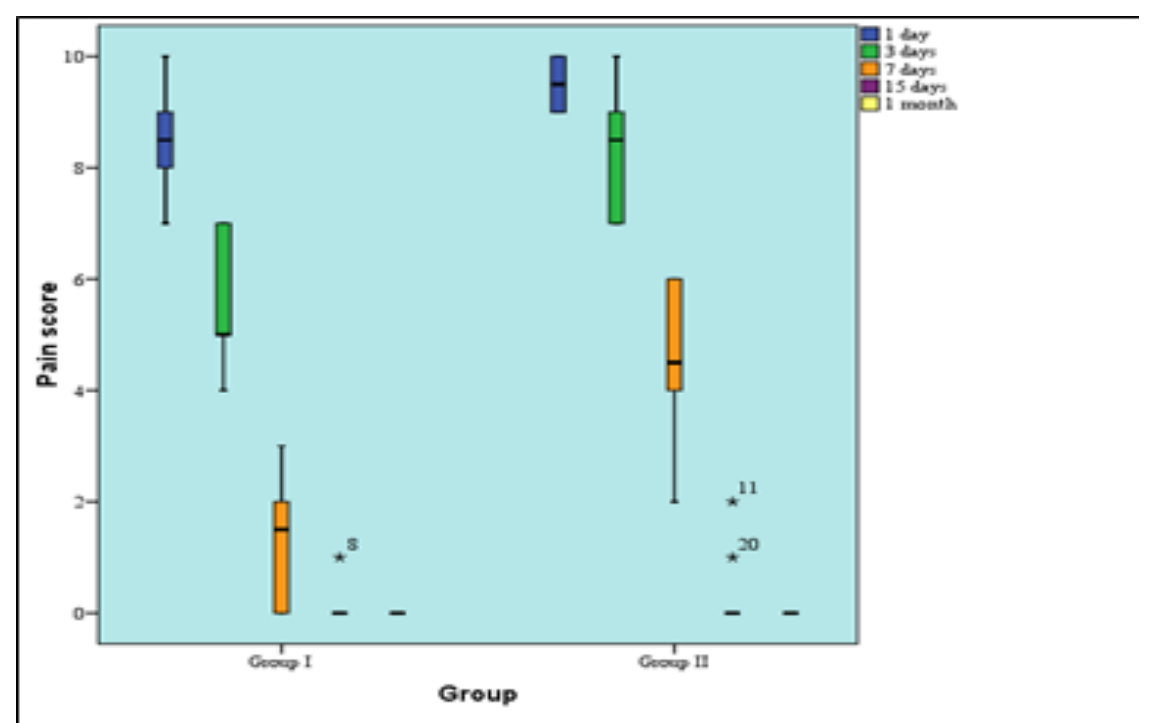

Figure 4: Box plot representing median and range values for pain scores in the two groups (Stars represent outliers).

\section{Facial Swelling:}

Results collected showed increase in facial dimensions in both groups. Yet it is to be noted that group I revealed mild increase within facial measurements at day 1 and 3 days postoperative followed by a marked decline at day 7 and 15 postoperative. In contrast
Group II demonstrated a significant increase in facial dimensions at day 1, 3, 7 and 15 consecutively. Data collected from both groups at 1 month postoperative were showed complete resolution of the swelling with facial measurements were similar to the immediate postoperative. (Table 3, Figure 5).

Table 3: Descriptive statistics and results of repeated measures ANOVA test for comparison between swelling in the two groups as well as the changes by time within each group:

\begin{tabular}{|c|c|c|c|c|}
\hline Time & $\begin{array}{l}\text { Group I } \\
(\mathrm{n}=10)\end{array}$ & $\begin{array}{l}\text { Group II } \\
(\mathrm{n}=10)\end{array}$ & $P$-value & $\begin{array}{l}\text { Effect size (Partial } \\
\quad \text { Eta Squared) }\end{array}$ \\
\hline \multicolumn{5}{|l|}{ Pre-operative } \\
\hline Mean (SD) & $10.02(0.35)^{\mathrm{B}}$ & $10.37(0.18)^{\mathrm{B}}$ & \multirow{2}{*}{$0.011^{*}$} & \multirow{2}{*}{0.308} \\
\hline $95 \% \mathrm{CI}$ & $9.84-10.2$ & $10.19-10.55$ & & \\
\hline \multicolumn{5}{|l|}{1 day } \\
\hline Mean (SD) & $10.98(0.56)^{\mathrm{A}}$ & $12.32(0.38)^{\mathrm{A}}$ & \multirow{2}{*}{$<0.001 *$} & \multirow{2}{*}{0.688} \\
\hline $95 \%$ CI & $10.66-11.3$ & $12-12.64$ & & \\
\hline \multicolumn{5}{|l|}{3 days } \\
\hline Mean (SD) & $10.94(0.54)^{\AA}$ & $12.4(0.36)^{\mathrm{A}}$ & \multirow{2}{*}{$<0.001^{*}$} & \multirow{2}{*}{0.737} \\
\hline $95 \% \mathrm{CI}$ & $10.64-11.25$ & $12.1-12.71$ & & \\
\hline \multicolumn{5}{|l|}{7 days } \\
\hline Mean (SD) & $10.09(0.41)^{\mathrm{B}}$ & $12.09(0.42)^{\mathrm{A}}$ & \multirow{2}{*}{$<0.001^{*}$} & \multirow{2}{*}{0.865} \\
\hline $95 \% \mathrm{CI}$ & $9.81-10.37$ & $11.81-12.37$ & & \\
\hline \multicolumn{5}{|l|}{15 days } \\
\hline Mean (SD) & $10.02(0.35)^{\mathrm{B}}$ & $10.69(0.17)^{\mathrm{B}}$ & \multirow{2}{*}{$<0.001^{*}$} & \multirow{2}{*}{0.625} \\
\hline $95 \% \mathrm{CI}$ & $9.84-10.2$ & $10.51-10.87$ & & \\
\hline \multicolumn{5}{|l|}{1 month } \\
\hline Mean (SD) & $10.02(0.35)^{\mathrm{B}}$ & $10.37(0.18)^{\mathrm{B}}$ & \multirow{2}{*}{$0.011^{*}$} & \multirow{2}{*}{0.308} \\
\hline $95 \% \mathrm{CI}$ & $9.84-10.2$ & $10.19-10.55$ & & \\
\hline $\begin{array}{l}P \text {-value (Changes } \\
\text { by time) }\end{array}$ & $<0.001 *$ & $<0.001 *$ & & \\
\hline $\begin{array}{l}\text { Effect size (Partial } \\
\text { Eta Squared) }\end{array}$ & 0.812 & 0.949 & & \\
\hline
\end{tabular}

*: Significant at $P \leq 0.05$, Different superscripts in the same column indicate statistically significant changes by time. 


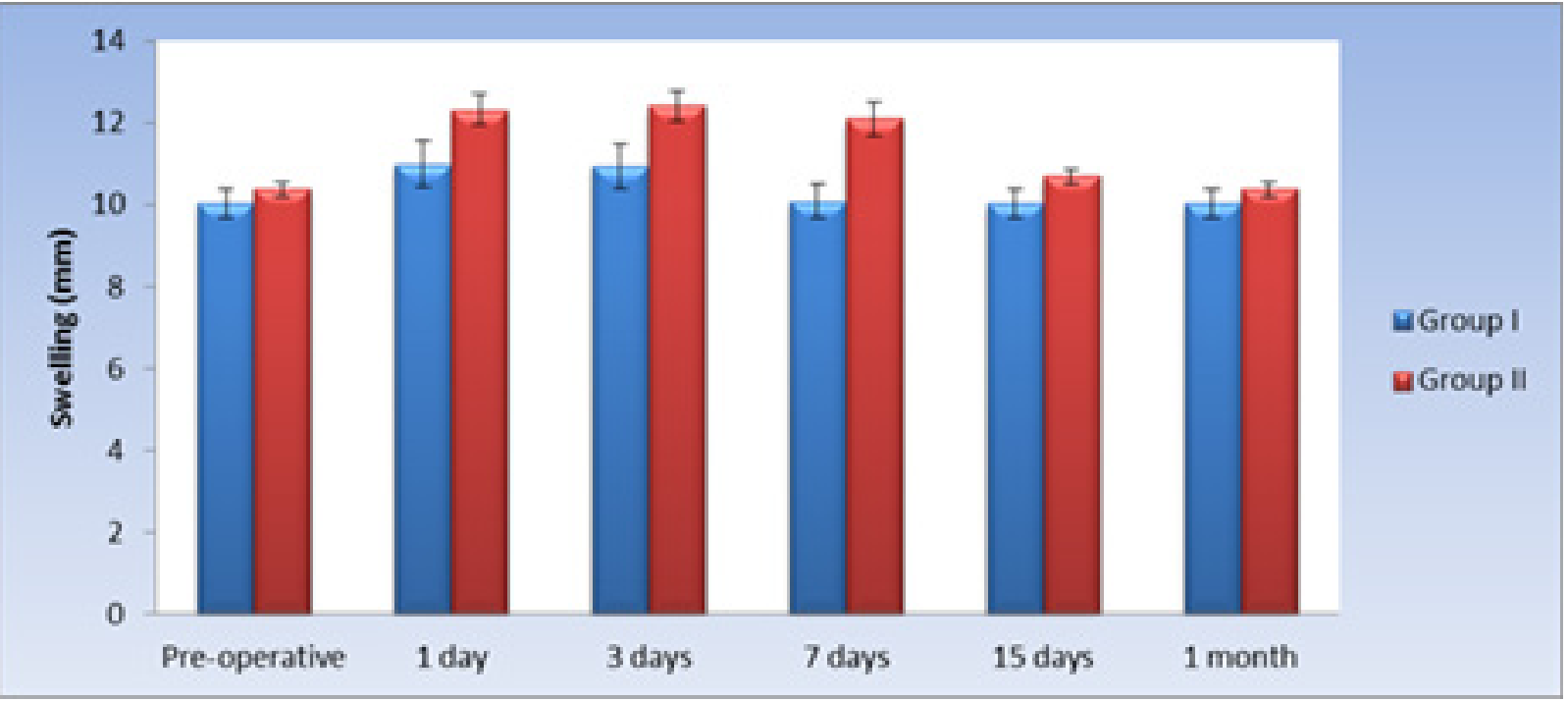

Figure 5: Bar chart representing mean and standard deviation values for swelling measurements in the two groups.

\section{Vestibular depth:}

Results gained in the present study showed that there was no preoperative significant difference between mean vestibular depths in the two groups. In contrast, at day $1,3,7,15$ days as well as 1 month. Group I showed statistically significant higher mean vestibular depth than Group II which experienced a significant decrease in mean vestibular depth. This reduction started at day 1 and continues decreasing till 1 month postoperative. (Table 4, Figure 6).

Table 4: Descriptive statistics and results of repeated measures ANOVA test for comparison between vestibular depth in the two groups as well as the changes by time within each group:

\begin{tabular}{|c|c|c|c|c|}
\hline Time & $\begin{array}{l}\text { Group I } \\
(\mathrm{n}=10)\end{array}$ & $\begin{array}{l}\text { Group II } \\
(\mathrm{n}=10)\end{array}$ & $P$-value & $\begin{array}{l}\text { Effect size (Partial } \\
\text { Eta Squared) }\end{array}$ \\
\hline \multicolumn{5}{|l|}{ Pre-operative } \\
\hline Mean (SD) & $13.91(0.44)$ & $14(0.24)^{\mathrm{A}}$ & \multirow{2}{*}{0.573} & \multirow{2}{*}{0.018} \\
\hline $95 \% \mathrm{CI}$ & $13.68-14.14$ & $13.77-14.23$ & & \\
\hline \multicolumn{5}{|l|}{1 day } \\
\hline Mean (SD) & $13.61(0.37)$ & $11.72(0.63)^{\mathrm{B}}$ & \multirow{2}{*}{$<0.001 *$} & \multirow{2}{*}{0.788} \\
\hline $95 \% \mathrm{CI}$ & $13.27-13.95$ & $11.38-12.06$ & & \\
\hline \multicolumn{5}{|l|}{3 days } \\
\hline Mean (SD) & $13.53(0.35)$ & $10.3(0.63)^{\mathrm{C}}$ & \multirow{2}{*}{$<0.001^{*}$} & \multirow{2}{*}{0.918} \\
\hline $95 \% \mathrm{CI}$ & $13.19-13.87$ & $9.96-10.64$ & & \\
\hline \multicolumn{5}{|l|}{7 days } \\
\hline Mean (SD) & $13.9(0.42)$ & $9.78(0.44)^{\mathrm{C}}$ & \multirow{2}{*}{$<0.001^{*}$} & \multirow{2}{*}{0.962} \\
\hline $95 \% \mathrm{CI}$ & $13.61-14.19$ & $9.49-10.07$ & & \\
\hline \multicolumn{5}{|l|}{15 days } \\
\hline Mean (SD) & $13.91(0.44)$ & $8.61(0.4)^{\mathrm{D}}$ & \multirow{2}{*}{$<0.001^{*}$} & \multirow{2}{*}{0.978} \\
\hline $95 \% \mathrm{CI}$ & $13.63-14.19$ & $8.33-8.89$ & & \\
\hline \multicolumn{5}{|l|}{1 month } \\
\hline Mean (SD) & $13.91(0.44)$ & $7.89(0.39)^{\mathrm{E}}$ & \multirow{2}{*}{$<0.001^{*}$} & \multirow{2}{*}{0.983} \\
\hline $95 \% \mathrm{CI}$ & $13.63-14.19$ & $7.61-8.17$ & & \\
\hline $\begin{array}{l}P \text {-value (Changes } \\
\text { by time) }\end{array}$ & 0.088 & $<0.001 *$ & & \\
\hline $\begin{array}{l}\text { Effect size (Partial } \\
\text { Eta Squared) }\end{array}$ & 0.464 & 0.998 & & \\
\hline
\end{tabular}

*: Significant at $P \leq 0.05$, Different superscripts in the same column indicate statistically significant changes by time. 


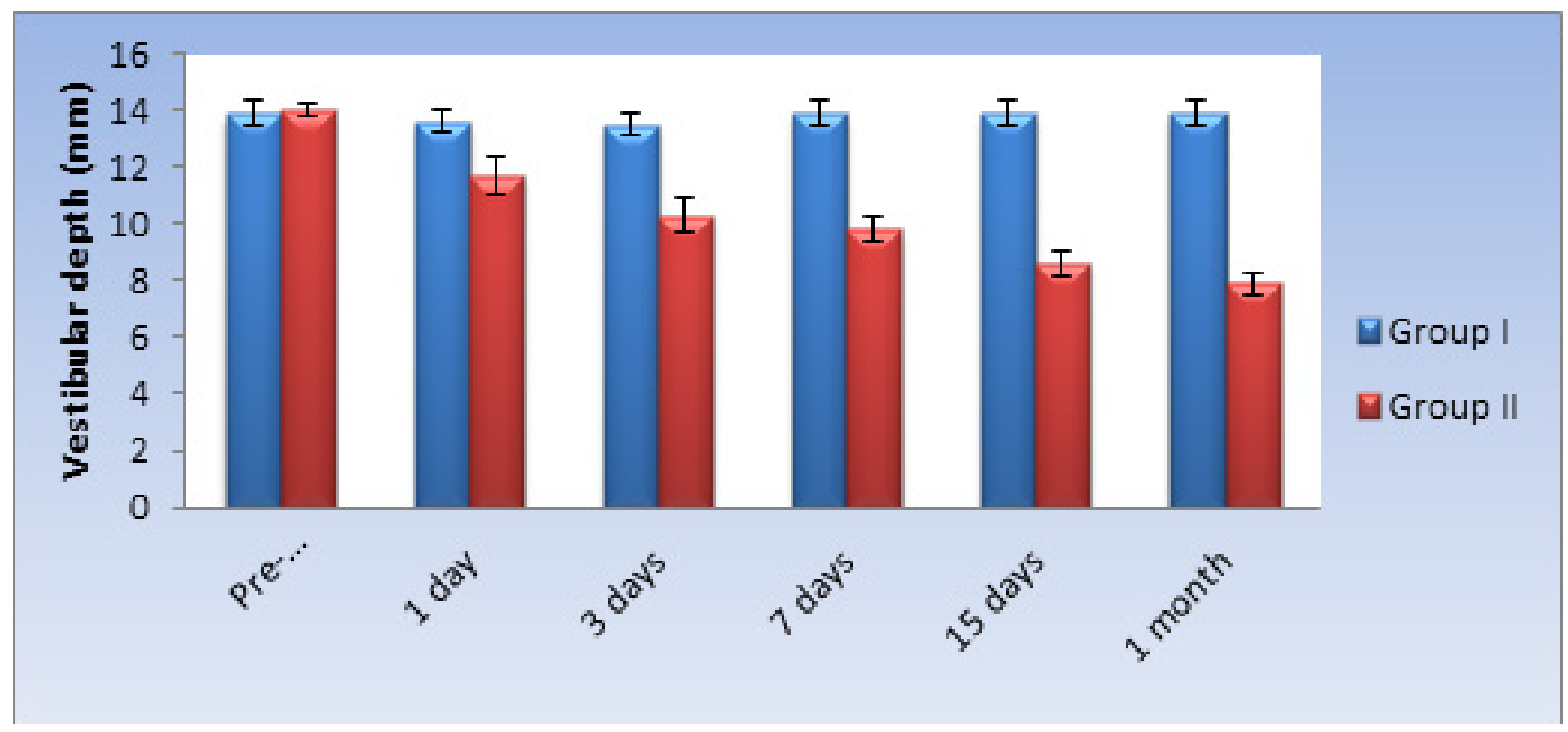

Figure 6: Bar chart representing mean and standard deviation values for vestibular depth measurements in the two groups.

\section{Presence of Oroantral communication:}

There were no clinical signs of persistence of OAC at any of the follow up period in both groups.

\section{Defect size:}

Cone beam CTs taken preoperatively confirmed the presence of communication with defect mean size range
$63.56 \pm 73.24$ in both groups. Recorded results evidently showed similar values for both groups at different time periods, so there was no statistically significant difference between the two groups (Figure 9).

As regards the changes by time, there was a marked decrease in defect size after 3 months as well as from 3 to 6 months. (Table 5, Figure 7).

Table 5: Descriptive statistics and results of repeated measures ANOVA test for comparison between defect size in the two groups as well as the changes by time within each group:

\begin{tabular}{|c|c|c|c|c|}
\hline Time & $\begin{array}{l}\text { Group I } \\
(\mathrm{n}=10)\end{array}$ & $\begin{array}{l}\text { Group II } \\
(\mathrm{n}=10)\end{array}$ & $P$-value & $\begin{array}{c}\text { Effect size (Partial } \\
\text { Eta Squared) }\end{array}$ \\
\hline \multicolumn{5}{|l|}{ Pre-operative } \\
\hline Mean (SD) & $68.4(7.29)^{\mathrm{A}}$ & $68.4(7.29)^{\mathrm{A}}$ & \multirow{2}{*}{1.000} & \multirow{2}{*}{0.000} \\
\hline $95 \% \mathrm{CI}$ & $63.56-73.24$ & $63.56-73.24$ & & \\
\hline \multicolumn{5}{|l|}{3 months } \\
\hline Mean (SD) & $30.1(3.4)^{\mathrm{B}}$ & $30.1(3.4)^{\mathrm{B}}$ & \multirow{2}{*}{1.000} & \multirow{2}{*}{0.000} \\
\hline $95 \% \mathrm{CI}$ & $27.83-32.37$ & $27.83-32.37$ & & \\
\hline \multicolumn{5}{|l|}{6 months } \\
\hline Mean (SD) & $15.9(2.96)^{\mathrm{C}}$ & $15.9(2.96)^{\mathrm{C}}$ & \multirow{2}{*}{1.000} & \multirow{2}{*}{0.000} \\
\hline $95 \% \mathrm{CI}$ & $13.93-17.87$ & $13.93-17.87$ & & \\
\hline $\begin{array}{l}P \text {-value (Changes } \\
\text { by time) }\end{array}$ & $<0.001 *$ & $<0.001 *$ & & \\
\hline $\begin{array}{l}\text { Effect size (Partial } \\
\text { Eta Squared) }\end{array}$ & 0.980 & 0.980 & & \\
\hline
\end{tabular}

*: Significant at $P \leq 0.05$, Different superscripts in the same column indicate statistically significant changes by time. 


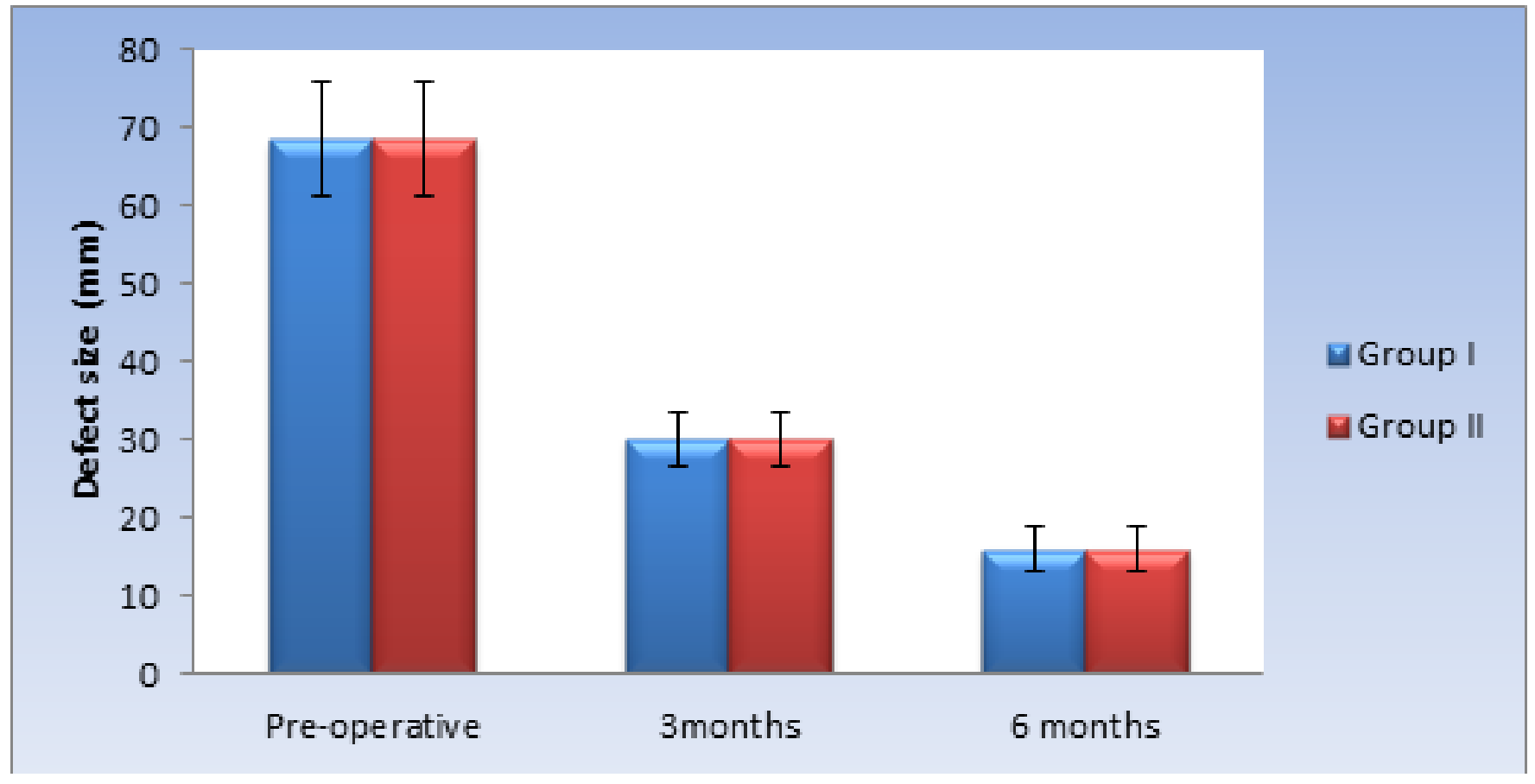

Figure 7: Bar chart representing mean and standard deviation values for defect size measurements in the two groups.

\section{Bone density:}

Both groups showed the same values at different time periods, so there was no statistically significant difference between the two groups. As regards the changes by time, there was a statistically increase in bone density after 3 months as well as from 3 to 6 months. (Table 6, Figure 9).

Table 6: Descriptive statistics and results of repeated measures ANOVA test for comparison between bone density in the two groups as well as the changes by time within each group:

\begin{tabular}{|c|c|c|c|c|}
\hline Time & $\begin{array}{l}\text { Group I } \\
(\mathrm{n}=10)\end{array}$ & $\begin{array}{l}\text { Group II } \\
(\mathrm{n}=10)\end{array}$ & $P$-value & $\begin{array}{c}\text { Effect size (Partial } \\
\text { Eta Squared) }\end{array}$ \\
\hline \multicolumn{5}{|l|}{ Pre-operative } \\
\hline Mean (SD) & $241.1(10.1)^{\mathrm{C}}$ & $241.1(10.1)^{\mathrm{C}}$ & \multirow{2}{*}{1.000} & \multirow{2}{*}{0.000} \\
\hline $95 \%$ CI & $234.39-247.81$ & $234.39-247.81$ & & \\
\hline \multicolumn{5}{|l|}{3 months } \\
\hline Mean (SD) & $603.2(19.3)^{\mathrm{B}}$ & $603.2(19.3)^{\mathrm{B}}$ & \multirow{2}{*}{1.000} & \multirow{2}{*}{0.000} \\
\hline $95 \% \mathrm{CI}$ & $590.4-616$ & $590.4-616$ & & \\
\hline \multicolumn{5}{|l|}{6 months } \\
\hline Mean (SD) & $638.1(21.8)^{\mathrm{A}}$ & $638.1(21.8)^{\mathrm{A}}$ & \multirow{2}{*}{1.000} & \multirow{2}{*}{0.000} \\
\hline $95 \% \mathrm{CI}$ & $623.62-652.58$ & $623.62-652.58$ & & \\
\hline $\begin{array}{l}P \text {-value (Changes } \\
\text { by time) }\end{array}$ & $<0.001 *$ & $<0.001 *$ & & \\
\hline $\begin{array}{l}\text { Effect size (Partial } \\
\text { Eta Squared) }\end{array}$ & 0.996 & 0.996 & & \\
\hline
\end{tabular}

*: Significant at $P \leq 0.05$, Different superscripts in the same column indicate statistically significant changes by time. 


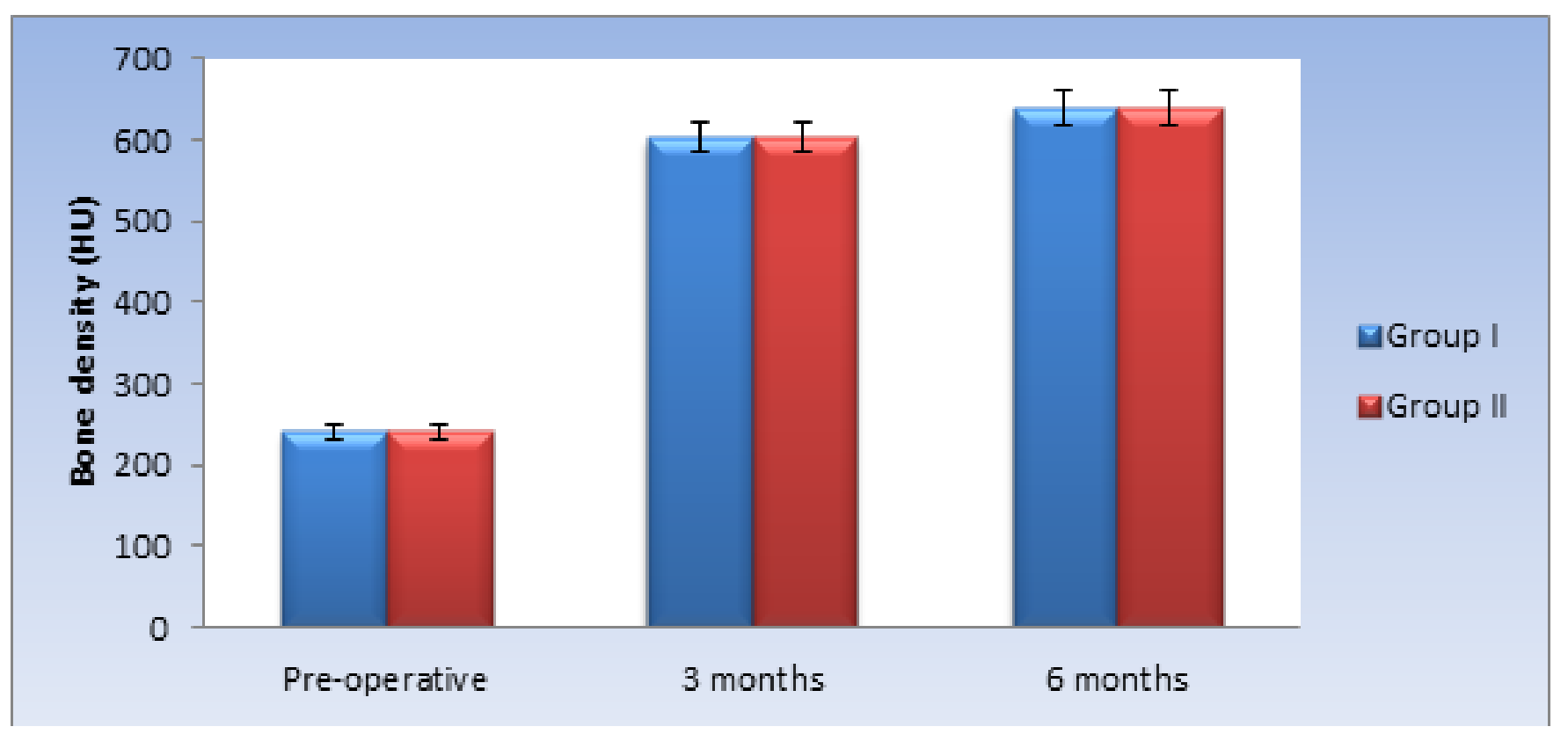

Figure 8: Bar chart representing mean and standard deviation values for bone density measurements in the two groups.

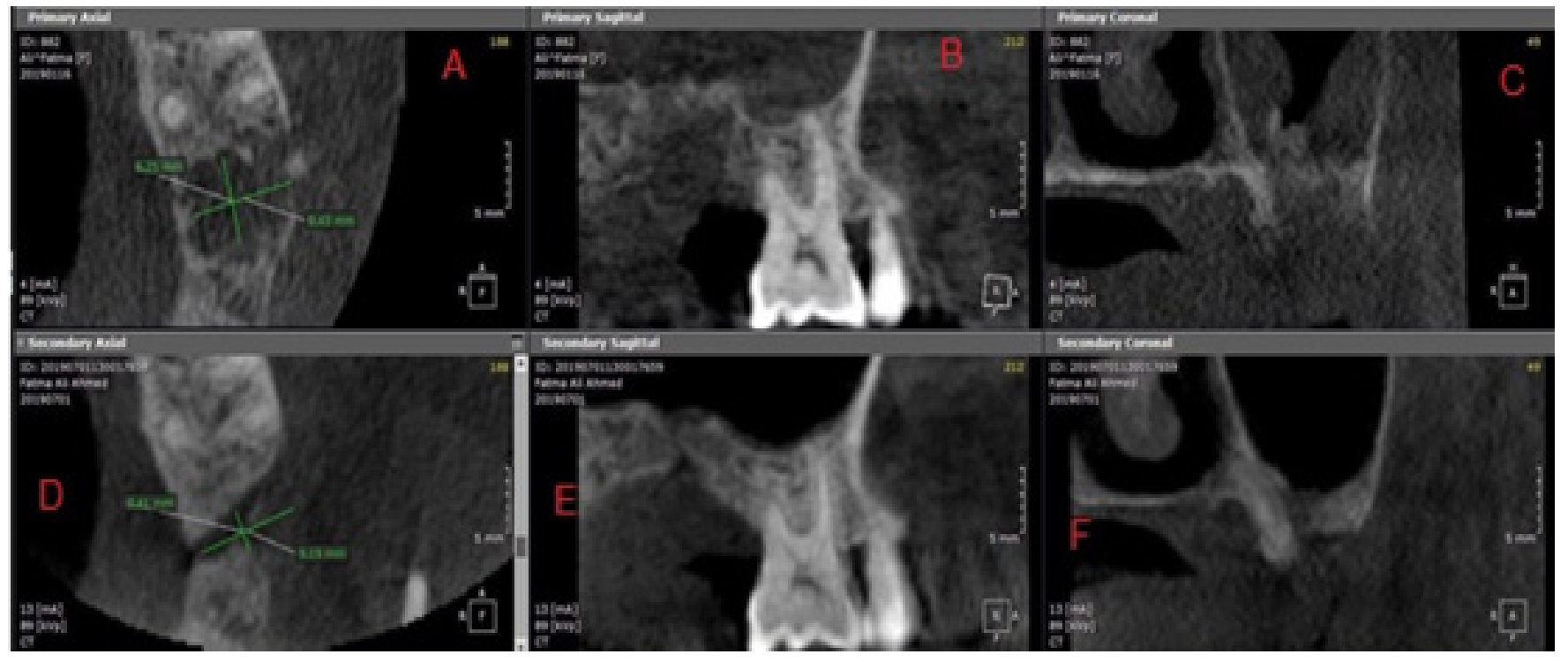

Figure 9: A, B, C showing preoperative CBCT images of the defect size and density at axial, Sagittal a d coronal plane. D, E, F showing postoperative 6 months

CBCT images.

\section{DISCUSSION}

Our present study aimed to qualify the efficacy of cyanoacrylate (periacryl 90) versus the buccal advancement flap for competent closure of immediate Oroantral communication. Comparisons were based on clinical symptoms and radiographical findings.

Concerning the demographic data our present results concerning gender distribution was aligning with previous studies were the male preponderance was noted and was attributed to the type and hardness of bone. The mean age of patients with the incident was also congruent to other studies which claimed the higher incidence is at the third decade of life and provided an explanation that the maxillary sinus reaches its maximum size by this age which makes it prone to get violated during extraction ${ }^{[34]}$.

Clinical results attained in the current study are congruent with those of Buric ${ }^{[20]}$ in 2013 in a study evaluating the 
efficiency of cyanoacrylates in flapless closure of Oroantral communication. Results were in favor of the acrylates as they presented minimal postsurgical morbidity and the defect was completely sealed as manifested clinically and confirmed by radiographs taken two months postoperative. It is worth mentioning that collagen pellets were used for the application of the acrylate to prevent its leakage outside the socket as the case in our study.

Likewise Choi, et $a l^{[29]}$ documented the efficacy of cyanoacrylates in the repair of the schneiderian membrane in rabbits during sinus lift and their results were verified histologically showing complete healing in the membrane with no signs of infection this in contrast to the contralateral side which was left to heal spontaneously and showed signs of delayed healing and infection.

It is worth mentioning that Cyanoacrylates proved effective in various surgical maneuvers due to its ability to potentiate healing by establishing a strong bond to skin or mucosa via swift polymerization once in contact with blood or tissue fluid ${ }^{[35]}$. These properties allowed cyanoacrylates to provide hemostasis within the surgical field, efficiency in closure of incisions in delicate areas e.g eyelids with better esthetics, its aptness to stabilize fresh bone grafts in place till the entire healing process is completed and to decrease incidence of infection within the surgical site by forming an intact barrier against bacterial ingress ${ }^{[36-38]}$.

Likewise, Giray et $a l^{[39]}$ designed a clinical and microscopic study comparing mucosal wounds closed with sutures versus but cyanoacrylate adhesive in 15 patients. Results revealed significant pain and edema on the sutured side at day 1 and 2. while at days 3, 7 and 14 no significant difference was noticed between the two groups. However, at day 21 , scar formation was greatly marked on the sutured site.

In contrast, to our findings several articles reported the histotoxicity of cyanoacrylates together with the associated emission of heat which can lead to severe tissue damage ${ }^{[40]}$. This was not noticed in our present study due to the new chemical composition of the periacryl and the use of Butyl long chains which decreases the heat emission and is by far less histotoxic than previous forms.

Regarding Group II patients they performed buccal advancement flap for closure of the communication. Results collected here are similar to those of Borgonovo et $a l^{[41]}$ and Patel et $a{ }^{[42]}$ in two separate studies noted on the ease of the procedure and its competence with nearly no recurrence of the communication. However, as any surgical procedure the buccal advancement flap is associated with surgical comorbidity including pain and facial swelling which lasts for a considerable period of time. However, the most important drawback of the procedure is the decrease of the sulcular depth which compromises the oral hygiene and any planned prosthetic rehabilitation ${ }^{[43]}$.

It is worth noting that majority of the patients get alarmed knowing they have to perform a surgical procedure as they totally prefer the minimal invasive procedure if it provides the same or better outcome ${ }^{[44]}$.

Cone beam CT was the method of assessment in our study following the recommendations of previous articles where they advocated the ability of CBCT to assess the size of the defect and to characterize the bone density and the mucosa surrounding the perforation. Thus CBCT can be a beneficial modality to confirm the presence of the defect and to evaluate the healing process by measuring the size and bone density within the defect ${ }^{[45,46]}$.

Regarding the final outcome of our present study and comparing it to previous researches it is apparent that the buccal sliding flap and the flapless application of cyanoacrylate are both reliable treatment procedures for immediate Oroantral communication. However, the flapless cyanoacrylate offers an easy, reliable treatment method bypassing all comorbidities associated with surgical intervention. This is followed by the previously mentioned pain and swelling in the immediate postoperative phase while on the long run emerges the decreased sulcular depth.

\section{CONCLUSION}

Cyanoacrylates provide a simple reliable procedure for closure of immediate Oroantral communications.

\section{CONFLICT OF INTEREST}

The authors declare no conflict of interest.

\section{REFERENCES}

1. Car M, Juretic M. Treatment of oroantral communications after tooth extractions. Is drainage into the nose necessary or not?. Acta Otolaryngol 1998; 118: 844 - 6.

2. Lewusz-Butkiewicz K, Kaczor K, Nowicka A. Risk factors in oroantral communication while extracting the upper third molar: Systematic review. Dent Med Probl. 2018; 55 (1): 69 - 74.

3. Dym H, Wolf J. Oroantral Communication. Oral and Maxillofacial Surgery Clinics 2012; 24 (2): $239-247$

4. Franco-Carro B, Barona-Dorado C, MartínezGonzález MJ-S, Rubio- Alonso L-J, MartínezGonzález J-M. Meta-analytic study on the frequency and treatment of oral antral communications. Med Oral Patol Oral Cir Bucal. 2011, 1; 16 (5): e682 - 7.

5. Khandelwal P, Hajira N. Management of Oro-antral Communication and Fistula: Various Surgical Options. World J Plast Surg. Jan 2017; (1): 3 - 8 . 
6. Lin PT, Bukachevsky R, Blake M. Management of odontogenic sinusitis with persistent oro-antral fistula. Ear Nose Throat J. Aug 1991; 70: 488 - 90.

7. Kretzschmar DP, Kretzschmar JL. Rhinosinusitis: review from a dental Perspective. Oral Surg Oral Med Oral Pathol Oral Radiol Endod. 2003; 96 (2): $128-35$.

8. Parvini P, Obreja K, Begic A, Schwarz F, Becker J, Sader R, Salti L. Decision-making in closure of oroantral communication and fistula. International Journal of Implant Dentistry. 2019 Apr; 5 (1), 13.

9. Peñarrocha-Oltra D, Rocio Alonso-González R, Pellicer-Chover H, , Aloy-Prósper A, PeñarrochaDiago M. Closure of Oroantral Communication with Buccal Fat Pad after Removing Bilateral Failed Zygomatic Implants: A Case Report and 6-month Follow-Up. J Clin Exp Dent 2015 Feb 1; 7 (1): e159 - 62.

10. Pauly G, Kashyap RR, Shetty R, Kini R, Rao PK., Girish Y R Oroantral fistula: Radiodiagnostic lessons from a rare case. A J Diagn Imaging. 2017 July 2 (1): Muglali M, Ozak A, Yarım M, Nural MS, Celebi N, TAksoz T Assessment of the Effects of Curacel and Bone Wax on the Acute Oroantral Opening Site by Means of Computer Tomography and Histopathology. J Maxillofac Oral Surg 2012 Jun; 11(2):160 - 5 .

11. Visscher SH, van Minnen B, Bos RRM. Closure of Oroantral communications: a review of the literature. J Oral Maxillofac Surg 2010 Jun; 68 (6): 1384 - 91.

12. Abuabara A, Cortez ALV, Passeri LA, de Moraes M, Moreira RWF. Evaluation of different treatments for oroantral/oronasal communications: experience of 112 cases. Int J Oral Maxillofac Surg. 2006 Feb; 35 (2): 155 - 8.

13. Nezafati S, Vafaii A, Ghojazadeh M: Comparison of pedicled buccal fat pad flap with buccal flap for closure of oro-antral communication. Int $\mathrm{J}$ Oral Maxillofac Surg 2011 Dec 41 (5): 624 - 8.

14. Parvini P, Obreja K, Sader R, Becker J, Schwarz F, Salti L. Surgical Options in Oroantral Fistula Management: A Narrative Review Int J Implant Dent 2018 Dec 27; 4 (1): 40.

15. Kwon M-S, Lee B-S, Choi B-J, Lee J-W, Ohe J-Y, Jung J-H, Hwang B-Y, Kwon Y-D. Closure of oroantral fistula: a review of local flap techniques. J Korean Assoc Oral Maxillofac Surg 2020 Feb; 46 (1): 58 - 65 .

16. Moumine M, Khalfi L, Faical Choumi. Uses of tongue flaps in oroantral communication. J Oral Med Oral Surg June 2018; 24: 63 - 66.

17. Assad M, Bitar W, Mohammed Nasser Alhajj MN.Closure of Oroantral Communication Using Platelet-rich Fibrin: A Report of Two Cases. Ann Maxillofac Surg 2017 Jan-june; 7 (1): 117 - 119.

18. Demetoglu U, Ocak H, Bilge S. Closure of Oroantral Communication With Plasma-Rich Fibrin Membrane. The Journal of Craniofacial Surgery, 2018 June, 29 (4): e367 - e370.

19. Buric N. Use of N-Butyl Cyanoacrylate with Metacryloxisulfolane (Glubran 2) Surgical Glue for Flapless Closure of Oroantral Communication. Implant Dent 2013 Jun; 22 (3): 238 - 43.

20. Singer A J and H. C. Thode H C, A review of the literature on octylcyanoacrylate tissue adhesive. The American Journal of Surgery, 2004 Feb vol. 187 (2); $238-248$.

21. Al-Belasy FA, Amer MZ, "Hemostatic effect of n-butyl- 2-cyanoacrylate (histoacryl) glue in warfarin-treated patients undergoing oral surgery. J Oral Maxillofac Surg 2003 Dec; 61 (12): 1405 - 9.

22. Habib A, Mehanna A, Medra A. Cyanoacrylate: A Handy Tissue Glue in Maxillofacial Surgery: Our Experience in Alexandria, Egypt. J. Maxillofac. Oral Surg. (2013 July-Sept ) 12 (3): $243-247$.

23. Vote B J, Elder M J.Cyanoacrylate Glue for Corneal Perforations: A Description of a Surgical Technique and a Review of the Literature. Clin Exp Ophthalmol. 2000 Dec; 28 (6): 437 - 42.

24. Aslan G, Men S, Gủlcủ A, Kefi A, Esen A Percutaneous embolization of persistent urinary fistula after partial nephrectomy using N-butyl-2cyanoacrylate. International Journal Of Urology. 2005 Sept; 12 (9): 838 - 841.

25. Asan Z, Kilitic A. Use of cyanoacrylate to prevent cerebrospinal fluid fistulas after cranial surgery. $\mathrm{Br}$ J Neurosurg 2018 Oct; 32 (5): 544 - 547.

26. Hochuli-Vieira E, Pinto A C B, Pereira-Filho V A, Saska S, Monnazzi M S. Adhesives Based on 
Butyl-Cyanoacrylate for Fixation of Autologous Bone Graft: Pilot Study in Rabbits. Dent Traumatol. 2017 Aug; 33 (4): 261 - 268.

27. Magee Jr WP, Ajkay N, Githae B, Rosenblum R S.Use of octyl-2-cyanoacrylate in Cleft Lip Repair. Ann Plast Surg. 2003 Jan; 50 (1): 1 - 5.

28. Choi B-H, Kim B-Y, Huh J-Y, Lee S-H, Zhu S-J, Jung J-H, Li J. Cyanoacrylate Adhesive for Closing Sinus Membrane Perforations During Sinus Lifts. J Craniomaxillofac Surg 2006 Dec; 34 (8): 505 - 9.

29. Bozkurt M K, Saydam L .The Use of Cyanoacrylates for Wound Closure in Head and Neck Surgery. Eur Arch Otorhinolaryngol. 2008 Mar; 265 (3): 331 - 5.

30. Sagar P, Prasad K, Lalitha R M , Ranganath $\mathrm{K}$. Cyanoacrylate for Intraoral Wound Closure: A Possibility? Int J Biomater. 2015 Nov; 2015: 16542.

31. Kaderi M A, Menaka, K B, Metgud R M, Gharat M R., Naik P S Ajbani J M., Naik P P, Aditi M. In-vitro evaluation of antibacterial potential of cyanoacrylate tissue adhesives for intraoral wound closure. Journal of Dental Materials and Techniques. 2017 Dec, 6 (4); 159 - 165.

32. Gabka J, Matsumara T. Measuring techniques and clinical testing of an anti-inflammatory agent (tantum). Munch Med Wochenschr 1971 Feb 5; 113 (6): 198 - 203.

33. PunwutikornJ,WailkakulA,Pairuchvej V.Clinically significant Oroantral communications - a study of incidence and site. Int J Oral Maxillofac Surg 1994 Feb: 23 (1); $19-21$.

34. Quinn J, Wells G, Sutcliffe T, Jarmuske M, Maw J, Stiell I, Johns P. A Randomized Trial Comparing Octylcyanoacrylate Tissue Adhesive and Sutures in the Management of Lacerations. 1997 May 21; 277 (19): 1527 - 30.

35. Al-Belasy A F, Zamer M Hemostatic effect of n-butyl-2-cyanoacrylate (histoacryl) glue in warfarin-treated patients undergoing oral Surgery. J Oral Maxillofac Surg. 2003 Dec, 61 (12) 1405 - 1409.

36. Salata L A,Mariguela V C, Antunes AA, G.GrossiOliveira G, Almeida A, Taba Jr. M. Short-term evaluation of grafts fixed with either N-butyl-2cyanocrylate or screws; J Oral Maxillofac Surg 2014 April; 72 (4): 676 - 682.

37. De Santis E, Silva E R, Martins E N C, Favero R, Botticelli R D, Xavier S P. Healing at the interface between autologous block bone grafts and recipient sites using n-butyl-2-cyanoacrylate adhesive as fixation: Histomorphometric study in rabbits, Journal of Oral Implantology, 2017 Dec; 43 (6); $447-455$.

38. Giray C B, Atasever, A, Durgun B, Araz K Clinical and electron microscope comparison of silk sutures and n-butyl-2-cyanoacrylate in human mucosa. Australian Dental Journal.1997; 42 (4); 255 - 258.

39. Jenkins L E, Davis L S.Comprehensive Review of Tissue Adhesives. Dermatol Surg 2018 Nov; 44 (11): 1367 - 1372.

40. Borgonovo AE, Berardinelli FV, Favale M, Maiorana C. Surgical options in oroantral fistula treatment. Open Dent J. 2012 June;6: $94-8$.

41. Patel R, Patel P, Kalariya V, Patel H, Chavda C. Closure of Oro-Antral Communication Using Buccal Advancement Flap .World J Plast Surg. 2019 May, 8 (2): 262 - 264.

42. Batra H, Jindal G, Kaur S. Evaluation of different treatment modalities for closure of oro-antral communications and formulation of a rational approach. J Maxillofac Oral Surg. 2010 March; 9 (1): 13 - 8 .

43. Devrukhkar V N, Hegde R J, S. S. Khare S $\mathrm{S}$, and T. A. Saraf, T A Evaluation of isoamyl 2-cyanoacrylate tissue adhesive in management of pediatric lacerations: An alternative to suturing. Ann Maxillofac Surg. Jan-Jun 2015; 5 (1): 49 - 54.

44. del Rey-Santamaria M, Valmaseda Castellon E, Berini Aytes L, Gay EC. Incidence of oral sinus communications in 389 upper third molar extraction. Med Oral Patol Oral Cir Bucal. 2006 July; 11 (4): E334 - 8.

45. Haidar R Z, Sivarajasingam V, Drage N A. The use of cone beam computed tomography in the management of displaced roots into the maxillary antrum. Oral Surgery. 2012 Feb; 5 (1); 18 - 21. 